\title{
Plasma and cerebrospinal fluid alfentanil, butorphanol, and morphine concentrations following caudal epidural administration in horses
}

\author{
Concentrações plasmáticas e no líquido cérebro-espinhal de alfentanil, butorfanol e morfina após \\ administração epidural caudal em eqüinos
}

\author{
Cláudio Corrêa Natalini ${ }^{1}$
}

\begin{abstract}
This study was conducted with the objective of determining the plasma and cerebrospinal fluid (CSF) concentrations after epidurally administered alfentanil, butorphanol, and morphine in horses. Five clinically healthy adult horses were studied. Morphine $0.1 \mathrm{mg} \mathrm{kg}^{-1}$, alfentanil $0.02 \mathrm{mg} \mathrm{kg}^{-1}$, and butorphanol $0.08 \mathrm{mg} \mathrm{kg}^{-1}$ in equal volumes $(20 \mathrm{ml})$ were epidurally injected. A 10-ml sample of CSF and blood were drawn at sampling times before the epidural administration and at 5, 10, 20, 30, 40, 50, 60 and 120 minutes, and hourly for 24 hours Enzyme-linked immonosorbent assay (ELISA) was used as the screening test to detect the injected opioids. ANOVA and Bonferroni's test were used with a $P$ values $<0.05$ considered significant. The ELISA method was used and seemed to be efficient to detect plasma and CSF epidurally administered alfentanil, butorphanol, and morphine in horses. Epidurally administered alfentanil produces fast cerebrospinal fluid levels that are higher than plasma levels. Less lipid soluble drugs such as morphine and butorphanol produce higher plasma levels than CSF levels for the same time point.
\end{abstract}

Key words: analgesia, opioids, pharmacokinetics, equine, epidural.

\section{RESUMO}

Este estudo foi realizado com o objetivo de se detectar as concentrações plasmáticas e no líquido cérebroespinhal de alfentanil, butorfanol e morfina administrados por via epidural caudal em cavalos. Foram utilizados cinco eqüinos adultos, clinicamente hígidos. Doses de morfina $\left(0,1 \mathrm{mg} \mathrm{kg}^{-1}\right)$, alfentanil $\left(0,02 \mathrm{mg} \mathrm{kg}^{-1}\right)$, e butorfanol $(0,08 \mathrm{mg}$ $\left.\mathrm{kg}^{-1}\right)$, diluídos em volume idêntico de $20 \mathrm{ml}$ em solução salina $0,9 \%$, foram administrados por via epidural. Uma amostra de $10 \mathrm{ml}$ de sangüe venoso e de líqüido cérebro-espinhal foram colhidas anteriormente à administração epidural e 5, 10, 20, 30, 40, 50, 60 e 120 minutos e a cada hora por 24 horas. O teste enzyme-linked immunosorbent assay (ELISA) foi utilizado como método analítico para detecção dos opióides. Os resultados foram avaliados com teste ANOVA e Bonferroni com valor de $P<0,05$. O teste de ELISA mostrou-se eficiente para deteç̧ão plasmática e no LCE de alfentanil, butorfanol, e morfina administrados por via epidural. A administração epidural de alfentanil em eqüinos produz níveis no líquido cérebro-espinhal mais rapidamente que no plasma. Opióides de maior hidrossolubilidade tais como morfina e butorfanol produzem níveis plasmáticos mais rapidamente do que no líquido cérebro-espinhal quando administrados por via epidural no cavalo.

Palavras-chave: analgesia, opióides, farmacocinética, eqüinos, epidural.

\section{INTRODUCTION}

The intravenous use of opioids has limitations in providing analgesia to the equine species. Side effects such as central nervous system excitation, locomotor stimulation, hypertension, and hyperthermia are dose dependent (TOBIN \& MILLER, 1979; TOBIN, 1978; COMBIE et al., 1979; TOBIN 1981; KAMERLING et al., 1985; TOBIN et al., 1979; COMBIE et al., 1981; PASCOE et al., 1993). Sympathetic stimulation and central nervous system (CNS) excitation are observed when opioids are systemically administered in horses. Narcotics such as morphine, fentanyl, pentazocine, and butorphanol are potent locomotor stimulants in the horse when administered intravenously (TOBIN \& MILLER, 1979; COMBIE, e al., 1981). The mechanisms for CNS excitation are unknown, but may be related to cerebral catecholamine release, especially norepinephrine and dopamine, and to opiate receptor

${ }^{1}$ Department of Veterinary Clinical Sciences, School of Veterinary Medicine, Louisiana State University. Baton Rouge, LA. 70803,

EUA. Email address: cnatalini@vetmed.lsu.edu. 
activation when high enough concentration of opioid drugs reach the CNS after a rapid intravenous injection (TOBIN \& MILLER, 1979; COMBIE, eal., 1981). Studies in horses have shown that these effects are blocked by catecholamine inhibition and opiate receptor antagonism with naloxone (TOBIN et al., 1979; COMBIE, e al., 1981).

When opioids are administered to horses through intramuscular route the central excitatory effects are not observed, mainly because high CNS drug concentrations are not achieved (TOBIN \& MILLER, 1979). Inappropriate analgesic response results from subcutaneous and muscular administration of mu opioid agonists such as fentanyl and its analogues in horses. Epidural opioids do not produce CNS excitation, behavior changes, or locomotor impairment in horses (NATALINI \& ROBINSON, 2000). Caudal epidural morphine administration produced long lasting analgesia on dermatomes of the caudal, sacral, lumbar, and thoracic area in horses. Caudal epidural administration of $0.02 \mathrm{mg} \mathrm{kg}^{-1}$ alfentanil and $0.08 \mathrm{mg} \mathrm{kg}^{-1}$ butorphanol in horses did not produce analgesic effects, behavioral or cardiovascular changes (NATALINI \& ROBINSON, 2000).

Epidurally administered opioids may spread within the epidural space, may be taken up into the epidural vasculature, may transfer to the subarachnoid space, and may be taken up into the epidural fat (COUSIN \& MATHER, 1984; WEDDEL \& RITTER, 1981; BERNARDS \& HILL, 1990). Epidural opioid analgesia requires diffusion from the site of injection to the opioid receptors of the spinal cord dorsal horn. In order to reach the receptors, opioids must diffuse through the spinal meninges; the dura mater, arachnoid mater, and pia mater (BERNARDS \& HILL, 1990). Spinal meningeal permeability to opioids has been shown to occur in dogs after the epidural administration of morphine. Lipid solubility and molecular weight quantitatively affect the spread of an epidurally administered opioid from the epidural space to the spinal cord receptors, although studies have demonstrated that hydrophobicity correlates better than molecular weight with permeability coefficients (COUSIN \& MATHER, 1984; BERNARDS \& HILL, 1990). In dogs and monkeys alfentanil is 3.7 times more permeable through the spinal meninges than morphine, and the authors suggested that the arachnoid mater was the major diffusion barrier between the epidural space and the spinal cord. Studies in humans and horses have shown that both lipid soluble and hydrophilic opioids such as alfentanil and morphine rapidly produce high plasma concentration after epidural injection (BERNARDS \& HILL, 1990; CODA et al., 1999). Although analgesic effects of alfentanil correlate well with plasma levels, analgesic effects of epidural morphine correlated very poorly with plasma concentrations (CODA et al., 1999; TAMSE N et al., 1983; CHAUVIN et al., 1981; DAHLSTROM et al.,1982; RAWAL et al., 1981; WEDDEL \& RITTER, 1981).

Several techniques can be employed for the detection of opioids in body fluids and blood in horses such as thin-layer chromatography, high-performance liquid chromatography, gas chromatography, gas chromatography/mass spectrometry, chemical ionization detection, and immunoassay. They are used to detect prohibited substances in performance horses or to determine opioid concentration in blood and urine in horses and human beings (TOBIN \& MILER, 1979; COMBIE et al., 1981; CODA et al., 1999; GERKEN \& SAMS, 1993). Immunologic methods are characterized by low limits of detection and high specificity. These methods are based on complex formation between an antigen and an antibody. Labeled antigen competes with unlabeled antigen in the sample for a limited number of antibody binding sites. As the concentration of antigen in the sample increases, less labeled antigen is able to bind to the antibody. After this interaction has been allowed to occur, bound or free labeled antigen is separated and measured by some means dependent on the nature of the label. The concentration of bound labeled antigen decreases as the concentration of unlabeled antigen increases (GERKEN \& SAMS, 1993; YAKSH et al., 1999).

Both radioimmunologic assays (RIA) and enzyme-linked immunosorbent assay (ELISA) are widely used as screening tests to detect opioids in horses and other species (PASCOE et al., 1993; GERKEN \& SAMS, 1993). Unlike chromatography methods, immunologic methods such as ELISA cannot distinguish between parent compounds and metabolites.

This study was conducted with the objective of determining the plasma and cerebrospinal fluid (CSF) concentrations after administered alfentanil, butorphanol, and morphine in horses.

\section{MATERIALS AND METHODS}

After approval by the Louisiana State University Institutional Animal Care and Use Committee, 5 clinically healthy mature horses, 2 geldings and 3 mares were studied. The body weight of the 5 horses was $511 \pm 47 \mathrm{~kg}$ (mean \pm SD) and the age was $10.8 \pm 2.2$ years (mean \pm SD). Horses were randomly assigned to three treatment groups. The agents were administered epidurally at periods no less than 7 days. 
For epidural injections an 18-gauge 3.0 inches epidural sterile needle ${ }^{\mathrm{a}}$ was placed in the first coccygeal space (Co1-Co2) in awake standing horses held in stocks. The space was located by palpation while manipulating the tail in a dorso-ventral direction. The skin over the region was clipped, surgically prepared, and covered with a sterile transparent dressing ${ }^{\mathrm{b}}$. After location of the first intercoccygeal vertebral space, the skin and subcutaneous tissue above the space were desensitized with 3ml 2\% lidocaine. Before injection, correct placement of the needle in the epidural space was assured by sterile water hanging drop technique and negligible resistance to air injection. To be sure that a venous sinus was not inadvertently penetrated, aspiration was performed before injection of the epidural agents. Morphine ${ }^{c}$ $0.1 \mathrm{mg} \mathrm{kg}^{-1}$, alfentanil ${ }^{\mathrm{d}} 0.02 \mathrm{mg} \mathrm{kg}^{-1}$, butorphanol ${ }^{\mathrm{e}} 0.08 \mathrm{mg}$ $\mathrm{kg}^{-1}$, in equal volume $(20 \mathrm{ml})$ were injected into the epidural space at a rate of $1 \mathrm{ml} 10$ seconds $^{-1}$.

For the subarachnoid catheter placement for CSF collection, landmarks were determined by palpating the caudal borders of the tuber coxae, the cranial borders of the tuber sacrale, and the midline depression between the sixth lumbar and the second sacral vertebrae. After sedation, all horses had the lumbosacral vertebral interspace clipped and the skin surgically prepared and covered with a sterile transparent dressing. The skin, subcutaneous tissue, and muscle at the lumbosacral region, the supraspinous and interspinous ligments were locally anesthetized with $10 \mathrm{ml}$ of $2 \%$ lidocaine. A 17 gauge, $17.78 \mathrm{~cm}$ epidural needle with stylet ${ }^{\mathrm{a}}$ was inserted perpendicularly along the median plane of the lumbosacral intervertebral space, until the lumbosacral subarachnoid space was reached. To confirm the successful subarachnoid needle placement, the needle stylet was removed, and a clear cerebrospinal fluid sample was withdrawn into a syringe. After appropriate placement, the bevel of the needle was directed cephalad and $20 \mathrm{~cm}$ of a sterile 19 gauge x $91.4 \mathrm{~cm}$ polyurethane spring-wire reinforced epidural anesthesia catheter ${ }^{\mathrm{f}}$ was advanced cranially through the needle into the subarachnoid space. The epidural needle was removed and the catheter was left in place, sutured to the skin and covered with sterile transparent dressing and gauze sponges. The catheter was flushed with $1 \mathrm{ml}$ of $10 \mathrm{IU} / \mathrm{ml}$ heparinized saline and left in place for 48 hours before the experiment started and left in place for the entire length of the experiment (total of 23 days). Horses were sedated with xylazine for subarachnoid catheter placement.

CSF and plasma morphine, alfentanil, and butorphanol concentrations were detected with ELISA kits $^{\mathrm{g}}$ with sensitivity limits of detection of $1 \mathrm{ng} \mathrm{ml} \mathrm{l}^{-1}$ or less. CSF samples were obtained from the subarachnoid catheter. Blood samples were obtained from the jugular vein through a venous catheter. A 10-ml sample of CSF and blood were drawn at sampling times before the epidural administration and at 5, 10, 20, 30, 40, 50, 60 and 120 minutes, and hourly for 24 hours. For determination of plasma opioid concentration, blood was collected in tubes containing $100 \mathrm{U}$ of heparin. Blood samples were centrifuged and plasma was harvested. Both plasma and CSF were frozen at $-20^{\circ} \mathrm{C}$ until analyzed.

Results were obtained using an ELISA microplate reader ${ }^{\mathrm{h}}$ set at a $650 \mathrm{~nm}$ wavelength. The optic density (OD) obtained for each well from the plate reader was converted to percentage binding $(\% \mathrm{~B} / \mathrm{Bo})$ by dividing the OD readings of known standard concentrations by the OD readings of the zero standard and multiplying by 100 . After \%B/Bo were calculated, standard \%B/Bo and concentration (ng/ml) curves for each opioid were used to determine the plasma and CSF concentrations over time. ELISA kits used were specific for each opioid, although the kits were not capable of differentiating the parent drug from its metabolites.

Quantitative data for CSF and blood samples, within groups and among groups were analyzed using two-way repeated measures analysis of variance and Bonferroni's test. A P value of $<0.05$ was considered significant. Data is expressed as mean \pm SD.

\section{RESULTS}

Collection of CSF was successfully obtained from the subarachnoid catheters over the 24 hour period in all horses, although the catheters had to be moved in some occasions to facilitate CSF withdrawal. No evidence of local inflammation was detected at the skin penetration site nor were clinical signs of central nervous system infection or inflammation noticed. The horses did not become ataxic and showed no signs of locomotor impairment after subarachnoid catheter placement.

The results of this study showed that plasma and CSF concentrations increased significantly from baseline for both alfentanil and butorphanol from 5 minutes to 24 hours after epidural administration (Figures 1 and 2). Morphine concentration in plasma increased significantly from 5 minutes to 24 hours after epidural injection. In the CSF significant increase in morphine concentration was detected from 30 minutes to 24 hours (Figure 3). In the alfentanil group, differences between plasma and CSF concentrations 


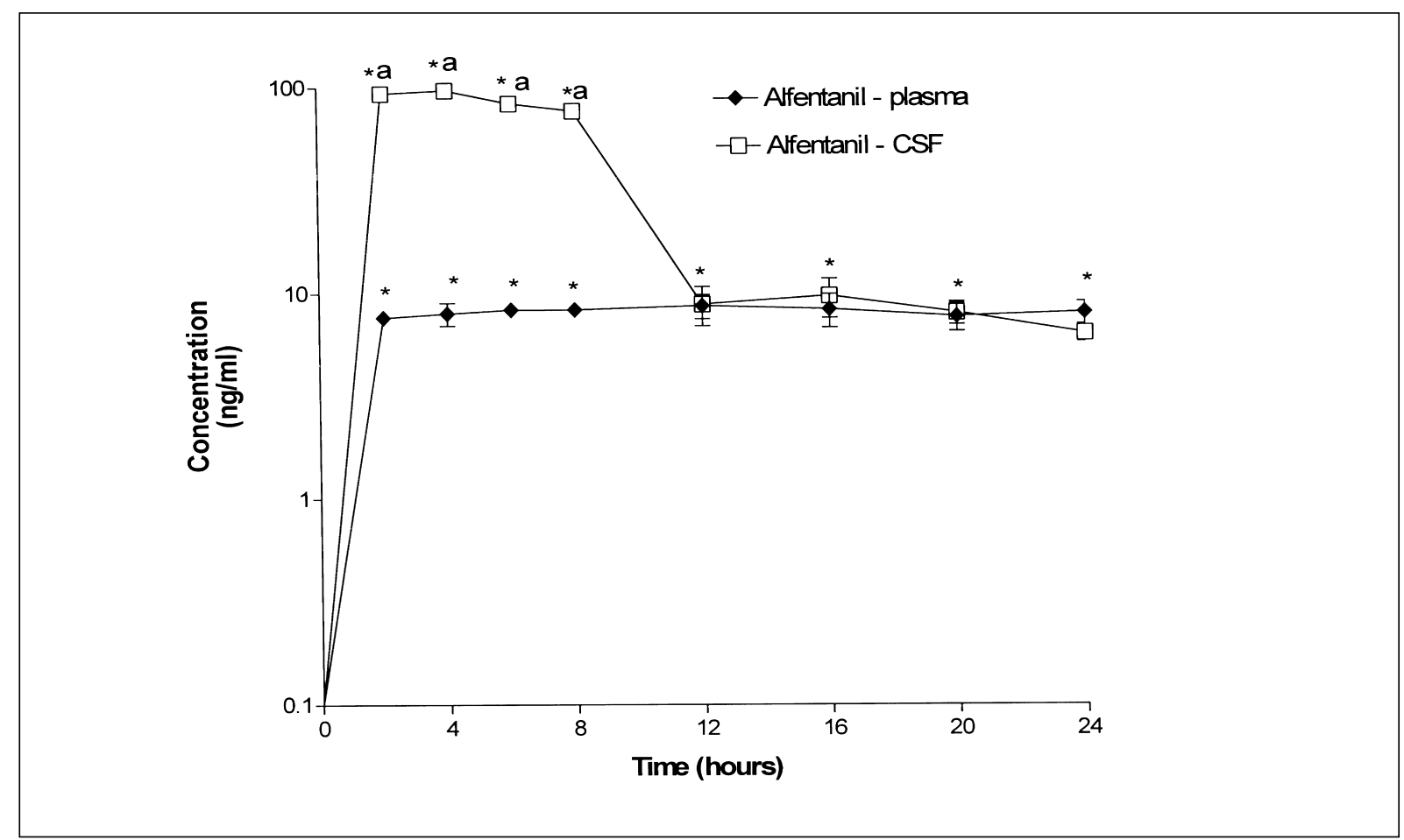

Figure 1 - Alfentanil concentrations (mean_SD) in plasma and CSF from 0 to 24 hours following caudal intercoccygeal epidural

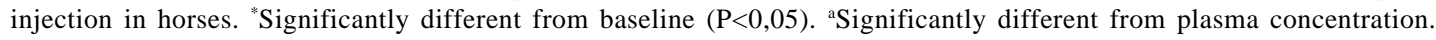

were significant from 60 minutes to 9 hours after epidural administration (Figure 2). In the butorphanol group, this difference was significant from 5 minutes to 16 hours after epidural injection (Figure 3). In the morphine group, differences in plasma and CSF concentrations were significant from 60 minutes to 4 hours and at 12 and 24 hours after injection (Figures 3). Plasma and CSF concentrations of alfentanil, butorphanol, and morphine were detected up to 24 hours after caudal epidural injection. Maximum plasma concentrations were $9 \mathrm{ng} \mathrm{ml}^{-1}$ from 10 minutes to 24 hours for alfentanil, $30 \mathrm{ng} \mathrm{ml}^{-1}$ from 4 to 16 hours for butorphanol, and 90ng $\mathrm{ml}^{-1}$ at 120 minutes for morphine. Maximum concentrations in CSF were $100 \mathrm{ng} \mathrm{ml}^{-1}$ from 60 minutes to 5 hours for alfentanil, 4ng ml-1 at 24 hours for butorphanol, and 40ng ml-1 at 13 hours for morphine.

\section{DISCUSSION}

Studies in human beings suggested that epidural administration of fentanyl or its derivatives such as alfentanil and sufentanil does not provide advantages when compared to intravenous administration as plasma levels higher than $10 \mathrm{ng} / \mathrm{ml}$ are achieved using either route (GLASS et al., 1992, SALOMAKI et al., 1991, SANDLER et al., 1992, CAMU
\& DEBUCQUOY, 1991, CHAUVIN etal., 1993, GELLER et al., 1993) Some authors suggested that epidural fentanyl produces analgesia by systemic absorption (GLASS et al., 1992; GELLER et al., 1993).

It has been reported that plasma concentrations of opioids correlate poorly with pharmacologic effects (COUSIN \& MATHER, 1984, STOELTING, 1999). In our study, plasma and CSF alfentanil, butorphanol and plasma morphine concentrations increased significantly 5 minutes following epidural injection, in a previous study we showed that there was no increase in the threshold for noxious electrical stimulation within the first 20 minutes for alfentanil and within the first 4 hours for morphine. We also found that $0.08 \mathrm{mg} \mathrm{kg}^{-1}$ epidural butorphanol produced no change in the threshold for noxious electrical stimulation at any time over the 24-hour study (NATALINI \& ROBINSON, 2000).

In one study, plasma alfentanil concentration up to 390ng ml-1 did not have MAC halothane sparing effect in horses, suggesting that no analgesic effect was obtained (PASCOE et al., 1993). In this present study we showed that 20 minutes after epidural administration of alfentanil, plasma and CSF concentrations were as low as $10 \mathrm{ng} \mathrm{ml}^{-1}$ Sixty minutes after epidural injection the CSF alfentanil concentration

Ciência Rural, v.36, n.5, set-out, 2006. 


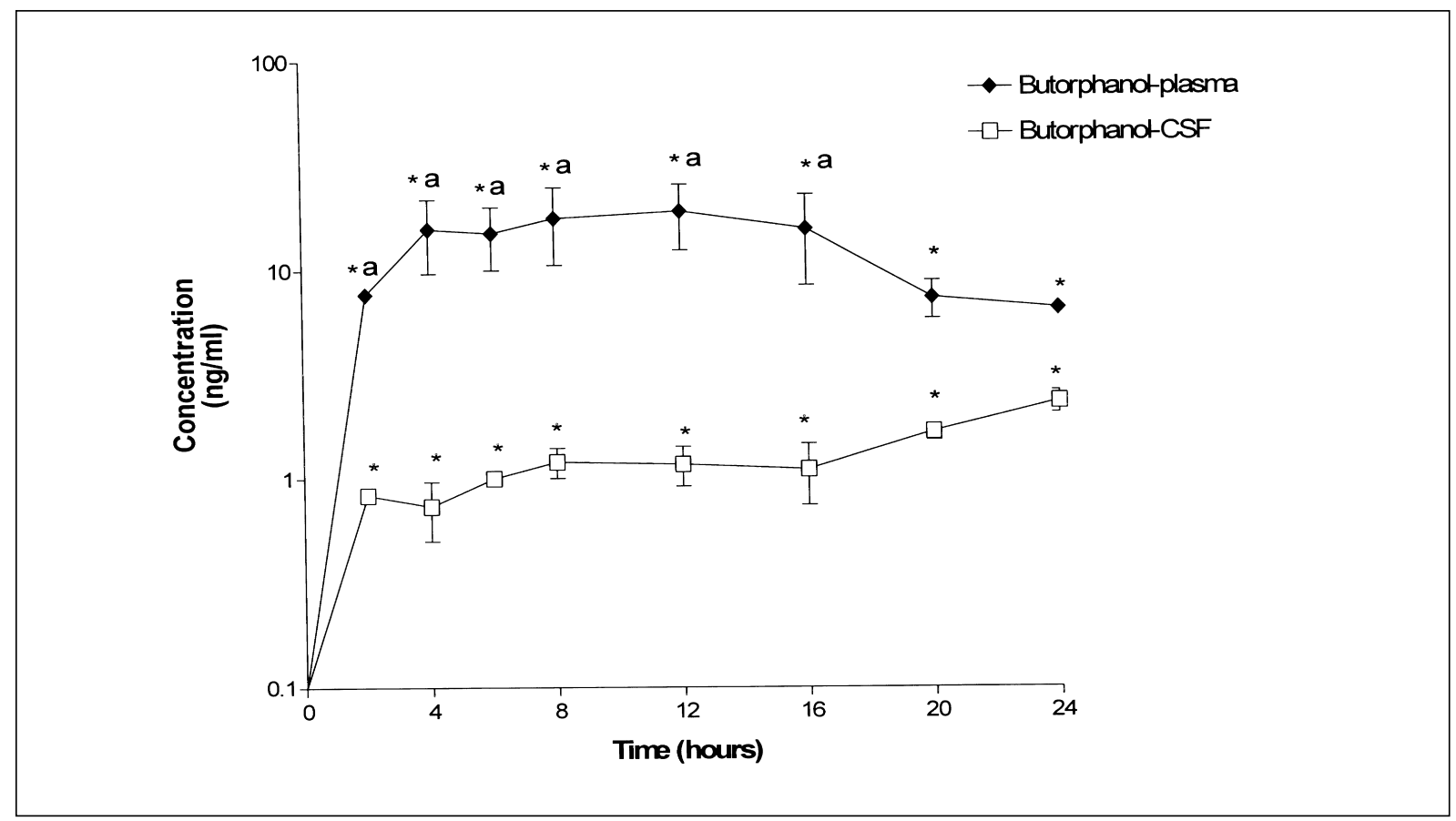

Figure 2 - Butorphanol concentrations (mean+SD) in plasma and CSF from 0 to 24 hours following caudal intercoccygeal epidural

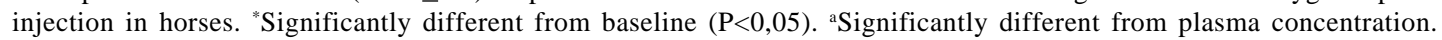

was $100 \mathrm{ng} \mathrm{ml}^{-1}$ and the plasma concentration was $10 \mathrm{ng}$ $\mathrm{ml}^{-1}$. It can e inferred that the epidural administration of alfentanil at $0.02 \mathrm{mg} \mathrm{kg}^{-1}$ produces minimal plasma levels and is probably not effective as an analgesic technique. Opioids epidurally administered need to diffuse through the dura mater, subarachnoid, and pia mater to gain access to the spinal cord opioid receptors. After epidural administration, alfentanil rapidly diffuses into the CSF and is readily available to penetrate the spinal cord tissue (CODA et al., 1999). This was demonstrated in our study where similar plasma and CSF concentrations were obtained after 5 minutes of epidural administration. The lower than expected plasma concentrations of alfentanil and its metabolites detected in our study by the ELISA method may have been due to distribution of the drug to other lipid-soluble tissues of the body. Fast diffusion of alfentanil into vascular spaces occurred and produced concentrations of approximately 10ng $\mathrm{ml}^{-1}$ from 10 minutes up to the end of the study at 24 hours. Between 12 and 24 hours, CSF concentrations of alfentanil declined and were almost identical to plasma concentrations. It is not known whether metabolites of alfentanil transferred between plasma and CSF over the period of our study in horses, but this could explain the similar concentration maintained in both compartments for the second half of the study period.
The concentration of morphine in the horses in our study was significantly higher in plasma than CSF from 60 to 120 minutes. Factors that may have contributed to this difference are the hydrophilic nature of morphine and its low CSF bioavailability after epidural injection. Similarly in humans plasma concentrations up to 25 times higher than CSF concentrations were described between 90 and 120 minutes after administration (NORBERG et al., 1983, SJOSTROM et al., 1987). Following epidural administration of highly ionized and hydrophilic drug such as morphine, only low concentrations of unionized drug will be present in solution. Thus, transferring of morphine to the subarachnoid space and CSF is slow with a peak at 90 minutes in human beings after lumbar epidural injection (TAMSEN et al., 1983). Penetration of the cord tissue will be slow since most of the drug present in the spinal fluid will be ionized. Only a small concentration gradient of unionized drug will be transferred to spinal cord receptors (COUSIN \& MATHER, 1984).

Results of our study demonstrated that peak morphine plasma concentration occurred after 60 minutes and peak CSF concentration was detected 2 hours after caudal epidural injection. Differences between human beings and horses can be explained by site of injection since we used dose rates similar to 


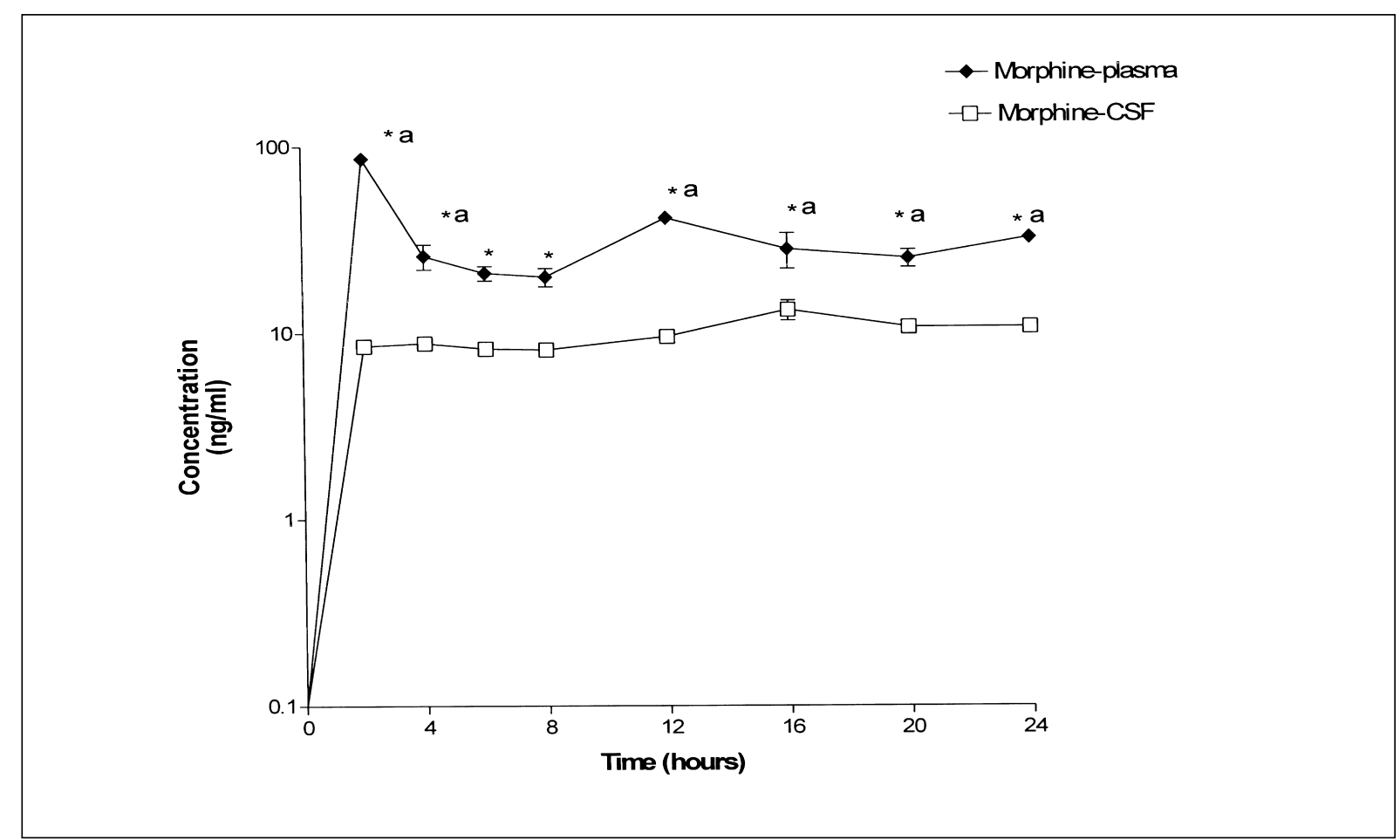

Figure 3 - Morphine concentrations (mean+SD) in plasma and CSF from 0 to 24 hours following caudal intercoccygeal epidural

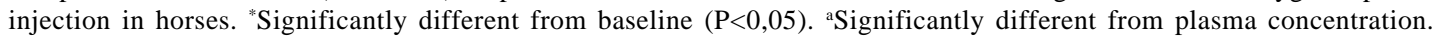

the dose rates used in human beings. Lumbar epidural injection in humans will deposit the drug in close proximity to the subarachnoid space and consequently it will transfer more quickly from the epidural to the subarachnoid space compared to intercoccygeal injection in horses in our study. It has been reported that increasing volume of the solution does not influence CSF plasma concentrations of morphine in humans (NORBERG et al., 1984; SCHEININ et al., 1986).

Data from our study demonstrates that epidurally administered butorphanol is rapidly detected in the plasma similar to findings for alfentanil and morphine and increases significantly in CSF after epidural administration similar to the more lipid soluble opioid alfentanil. It seems that water or lipid solubility is not the only determinant factor in transferring opioids from the epidural space to the plasma or subarachnoid space. Butorphanol has been shown to be rapidly and almost completely absorbed after intramuscular administration by producing rapid high plasma concentrations. Butorphanol is water soluble and chemically related to morphine although pharmacologically it has mu opioid antagonist and kappa agonist effects (STOELTING, 1999, ADAMS, 1995). In this present study, significantly higher plasma concentrations were detected from 1 to 16 hours. After this time period, a decrease in plasma concentration with concomitant increase in CSF levels occurred up to 24 hours. This can be explained if it is accepted that while plasma drug concentration decreases due to redistribution and metabolism, the mass of drug in CSF is less subject to biotransformation. The higher the molecular weight of butorphanol compared to alfentanil may explain the differences between them because while CSF butorphanol levels increased after 16 hours, alfentanil levels decreased in CSF after 10 hours of epidural administration.

In conclusion, the use of ELISA method for detection of epidurally administered alfentantil, butorphanol, and morphine is effective and produces the plateau shaped curves demonstrated in our study. Epidurally administered alfentanil produces fast cerebrospinal fluid levels that are higher than plasma levels. Less lipid soluble drugs such as morphine and butorphanol produce higher plasma levels than CSF for the same time point.

\section{ACQUISITION SOURCES}

a - Reusable Technique needle, Tuohy, thin wall, Becton Dickinson and Co. Franklin Lakes, NJ.

b - Bioclusiv, transparent dressing, Johnson \& Johnson Medical Inc. Arlington, TX.

Ciência Rural, v.36, n.5, set-out, 2006. 
c - Indumorph 200, Elkin-Sinn, Cherry Hill, NJ.

d - Alfenta, Janssen Pharmaceutica Inc. Titusville, NJ.

e - Stadol, Bristol-Myers Squibb Co. Princeton, NJ.

f - Arrow Epidural Anesthesia Catheter, Arrow International, Reading, PA 19605

h - THEMOmax, Molecular Devices Corporation, Sunnyvale, CA.

\section{REFERENCES}

ADAMS, R.H. Opioids. In: BOOTH, N.H.; MCDONALD, L.E. Veterinary pharmacology and therapeutics. Ames: Iowa State University, 1995. Cap.9, p.149-395.

BERNARDS, C.M.; HILL, H.F. Morphine and alfentanil permeability through the spinal dura, arachnoid, and pia mater of dogs and monkeys. Anesthesiology, Philadelphia, v.73, p.1214-1219, 1990.

CAMU, F.; DEBUCQUOY, F. Alfentanil infusions for postoperative pain: A comparison of epidural and intravenous routes. Anesthesiology, Philadelphia, v.75, p.171-176, 1991.

CHAUVIN, M. et al. Plasma pharmacokinetics of morphine after IM, extradural and intrathecal administration. British Journal of Anaesthesia, London, v.54, p.843-847, 1981.

CHAUVIN, M. et al. Equivalence of postoperative analgesia with patient-controlled intravenous or epidural alfentanil. Anesthesia and Analgesia, Philadelphia, v.76, p.1251-1258, 1993.

CODA, B.A. et al. Equivalent analgesia and side effects during epidural and pharmacokinetically tailored intravenous infusion with matching plasma alfentanil concentration. Anesthesiology, Philadelphia, v.90, p.98-108, 1999.

COMBIE, J. et al. Pharmacology of narcotic analgesics in the horse: selective blockade of narcotic-induced locomotor activity. American Journal of Veterinary Research, Chicago, v.42, p.716-721, 1981.

COMBIE, J. et al. The pharmacology of narcotic analgesics in the horse. IV. Dose and time response relationships for behavioral responses to morphine, meperidine, pentazocine, anileridine, methadone, and hydromorphone. Journal of Equine Medcine and Surgery, Philadelphia, v.3, p.377385, 1979.

COUSINS, M.J; MATHER, L.E. Intrathecal and epidural administration of opioids. Anesthesiology, Philadelphia, v.61, p.276-310, 1984.

DAHLSTROM, B. et al. Patient controlled analgesic therapy. IV: Pharmacokinetics and analgesic plasma concentrations of morphine. Clinical Pharmacokinetics, New Haven, v.7, p.266-279, 1982.

GELLER, E. et al. A randomized double-blind comparison of epidural sufentanil versus intravenous sufentanil or epidural fentanyl analgesia after major abdominal surgery. Anethesia and Analgesia, Philadelphia, v.76, p.1243-1250, 1993.
GERKEN, D.F.; SAMS, R.A. Factors affecting drug withhold time estimates in horses. Veterinary Clinics of North America: Equine Practice, Philadelphia, v.9, p.461-479, 1993.

GLASS, P.S.A. et al. Use of patient controlled analgesia to compare the efficacy of epidural to intravenous fentanyl administration. Anesthesia and Analgesia, Philadelphia, v.74, p.345-351, 1992.

KARMERLING, S. et al. Dose-related effects of fentanyl on autonomic and behavioral responses in performance horses. General Pharmacology, New York, v.16, p. 253-258, 1985.

NATALINI, C.C.; ROBINSON E.P. Comparative evaluation of the analgesic effects of epidural morphine, alfentanil, butorphanol, tramadol, and $\mathrm{U} 50488 \mathrm{H}$ in horses. American Journal of Veterinary Research, Chigaco, v.61, p.15791586, 2000.

NORBERG, G. et al. Pharmacokinetic aspects of epidural analgesia. Anesthesiology, Philadelphia, v.58, p.545-551, 1983.

NORBERG, G. Pharmacokinetic aspects of spinal morphine analgesia. Acta Anaesthesiologica Scandinavica, Helsinki, v.28, p.6-38, 1984.

PASCOE, P.J. et al. Evaluation of the effect of alfentanil on the minimum alveolar concentration of halothane in horses. American Journal of Veterinary Research, Chicago, v.54, p.1327-1332, 1993.

RAWAL, N. et al. Postoperative pain relief by epidural morphine. Anesthesia and Analgesia, Philadelphia, v.62, p.641-647, 1981.

SALOMAKI, T.E. et al. A randomized double-blind comparison of epidural versus intravenous fentanyl infusion for analgesia after thoracotomy. Anesthesiology, Philadelphia, v.75, p.790795, 1991.

SANDLER, A.N. et al. A randomized double-blind comparison of lumbar epidural and intravenous fentanyl infusions for posthoracotomy pain relief. Anesthesiology, Philadelphia, v.77, p.626-634, 1992.

SCHEININ, B. et al. Absorption of epidural morphine. Anaesthesia, London, v.41, p.1257-1258, 1986.

SJOSTROM, S. et al. Pharmacokinetics of epidural morphine and meperidine in humans. Anesthesiology, Philadelphia, v.67, p.877-888, 1987.

STOELTING, R.K. Opioid agonists and antagonists. In: Pharmacology and physiology in anesthetic practice. Philadelphia: Lippincott-Raven, 1999. p.77-112.

TAMSEN, A. et al. CSF and plasma kinetics of morphine and meperidine after epidural administration. Anesthesiology, Philadelphia, v.59, p.196, 1983. 
TOBIN, T. et al. The pharmacology of narcotic analgesics in the horse. III. Characteristics of the locomotor effects of fentanyl and apomorphine. Journal of Equine Medicine and Surgery, Philadelphia, v.3, p.284-288, 1979.

TOBIN, T; MILLER, J.R. The pharmacology of narcotic analgesics in the horse. I. The detection, pharmacokinetics and urinary clearance times of pentazocine. Journal of Equine Medicine and Surgery, Philadelphia, v.3, p.191-198, 1979.

TOBIN, T. Drugs and the performance horse. Springfield: Charles C. Thomas, 1981. 315p.
TOBIN, T. Narcotic analgesics and the opiate receptor in the horse. Journal of Equine Medicine and Surgery, Philadelphia, v.2, p.397-399, 1978.

WEDDEL, S.J.; RITTER, R.R. Serum levels following epidural administration of morphine and correlation with relief of post surgical pain. Anesthesiology, Philadelphia, v.54, p.210-214, 1981.

YAKSH, T.L. et al. Pharmacokinetics and efficacy of epidurally delivered sustained-released encapsulated morphine in dogs. Anesthesiology, Philadelphia, v.90, p.1402-1412, 1999. 